\title{
Which Demographic Characteristics of Directors Affected the Company Risk Level?
}

\author{
Andrea Lippi ${ }^{1} \&$ Maria Luisa Di Battista ${ }^{1}$ \\ ${ }^{1}$ Department of Business Administration, Faculty of Economics and Law, Università Cattolica del Sacro Cuore, \\ Piacenza, Italy \\ Correspondence: Andrea Lippi, Department of Business Administration, Faculty of Economics and Law, \\ Università Cattolica del Sacro Cuore, Piacenza, Italy. Tel: 39-0523-599-354. E-mail: andrea.lippi@ unicatt.it
}

Received: February 20, 2017

Accepted: March 5, 2017

Online Published: March 15, 2017

doi:10.5539/ijef.v9n4p119

URL: https://doi.org/10.5539/ijef.v9n4p119

\begin{abstract}
The board of directors is a group of people whose decision making can affect company life. In particular, the decision to have more liabilities than equity capital, makes a firm more aggressive than others in the market. The aim of this paper is to test the relationship between some demographic characteristics of directors and the firm's propensity to risk. In particular our analysis consider gender, age of the directors, independence and educational level. Moreover work experiences are considered. The results obtained should be considered by regulators and firm statutes as guidelines for future board composition.
\end{abstract}

Keywords: board of directors; decision making; corporate governance; leverage ratio

\section{Introduction}

Generally, boards of directors have at least four important functions: monitoring and controlling managers, providing information and counsel to managers, monitoring compliance with applicable laws and regulations, and linking the corporation to the external environment (Mallin, 2004; Monks \& Minow, 2003). Decisions taken by a board of directors should ensure the smooth running of the business, not only in terms of pursuing short-term economic interests, but also bearing in mind the future of the company and its long-term development.

The board of directors is composed of humans who have a natural tendency towards optimism (Kahneman, 2011). In particular, they may be victims of 'groupthinking' (Janis, 1971) or a tendency for a group to converge to the same, often optimistic, beliefs. Kahneman and Lovallo (1993) referencing Janis (1971) point out that 'organizational optimism' is self-reinforcing and pessimists and critical argument are ignored. One important task of the board of directors is to monitor the risk level of the company measured by the leverage ratio. The leverage ratio is the level of a company's debt related to its equity capital. A company with a higher leverage ratio is considered aggressive because it has more liabilities and less equity and therefore it may increase the probability of default (Agrawal, 2015) with dangerous consequences for stakeholders (Tsai et al., 2015).

Considering a sample of Italian listed companies, this paper aims to examine the relationship between their company risk level and the demographic characteristics of board members. The results obtained should be taken into consideration by firms and regulators in order to establish the composition of the board of directors.

\section{Hypotheses Development}

The demographic characteristics considered in the analysis are:

Gender diversity - It is well-established that women and men behave differently. Generally, women are more risk-averse (e.g. Jianakoplos \& Bernasek, 1998), whether they act individually or in making a team decision, while men are more overconfident than women (e.g. Lundberg et al., 1994; Barber \& Odean, 2000). Bearing these differences in mind, in this paper we test the following hypothesis:

H1: A larger number of female directors reduces the company risk level.

Board independence - The ability of a board to act as an effective monitoring mechanism lies in its independence from management (Beasley, 1996; Fama \& Jensen, 1983). The presence of independent directors is likely to enhance the levels of cognitive conflict on the board. In fact, independent directors share fewer 
experiences with management and they are liable to think more freely with regard to the firm's goals and possible alternatives. Thus the percentage of independent directors on a board is likely to have a direct negative effect on board cohesion (Forbes \& Milliken, 1999), which is considered one of the antecedent conditions of groupthink (Janis, 1971). In this paper we test the following hypothesis:

\section{H2: A larger number of independent directors reduces the company risk level.}

Age of board members - Botwinick (1977) and Burke and Light (1981) show that cognitive abilities including learning ability, memory and reasoning decrease as people age. Moreover, Carlson and Karlsson (1970) and Vroom and Pahl (1971) demonstrate that older executives tend to avoid risky decisions. Campbell (1987) highlights that younger managers seem to handle new and creative ideas better than older managers; according to Guthrie and Olian (1991) they tend to implement more risky and innovative growth strategies. We test the following hypothesis:

\section{H3: Older boards of directors tend to reduce the company risk level.}

Educational background and work experience of board members - Hambrick and Mason (1984) highlight the fact that strategies and effectiveness of an organization are substantially shaped by the demographic characteristics of top executives such as educational level, age, tenure, and gender.

In many studies (e.g. Hambrick \& Mason, 1984; Wiersema \& Bantel, 1992; Datta \& Rajagopalan, 1998; Wailderdsak \& Suehiro, 2004) educational level is considered as a good proxy for human capital, knowledge, or intellectual competence. In literature not only is the educational level taken into consideration, but also the subject studied is considered. Christy et al. (2010) show that the proportion of board members holding a financial degree is negatively associated with the market risk of equity in Australia. In theory, we believe that graduates could positively affect the decision making process among board members; however we believe that degrees do not confer the same level of skills. In a recent study, Litov et al. (2013) find that lawyers directors reduce corporate risk-taking and increase firm value. Audretsch and Lehmann (2006) argue that directors with academic backgrounds can enhance the competitive advantage of firms by facilitating access to and the absorption of external knowledge spillover. Considering the complex and sensitive decisions that a board of directors is called upon to assume, we believe that to have a degree in economics can impact positively on the decisions taken in the company interests and consequently on its risk level. Hence, in this paper we test the following hypotheses:

H4: Having a degree in economics reduces the company risk level.

Moreover, other studies indicate that board diversity is an important factor influencing board efficacy and firm performance (Carter et al., 2003; Adams \& Ferreira, 2009; Anderson et al., 2011; Gul et al., 2011). Milliken and Martins (1996) note that diversity increases the aggregate level of resources at the group's disposal but it is also associated with high levels of conflict, interaction difficulties, and lower levels of integration. Moreover, board members have few opportunities to diminish or smooth over the differences that separate them because they only interact periodically. Thus board diversity can lead to higher levels of cognitive conflicts (Williams \& O'Reilly, 1998) so boards whose members have diverse backgrounds are also likely to be less cohesive. Bearing in mind this uncertainty of guidance, in this paper we do not express a directional hypothesis but we test whether the diversification of degrees amongst board members and the diversification of board members' work experiences affect (and how) the risk level of the company.

\section{Data and Methodology}

We consider 126 listed companies on the Italian Stock Exchange at the year-end from 2011 to 2013 belonging to three main economic sectors: industrial, consumer goods and services, and public services. We do not consider the financial sector in the analysis because the comprehensive set of reform measures to strengthen the regulation, supervision and risk of the banking sector, known as Basel III, had a strong impact on the determination of the leverage ratio of banks; for this reason we excluded this sector from the survey. We consider 2011 as the first year of analysis because in that year the Italian Law 120/2011 established that the statute of each listed company must provide a policy for the allocation of directors that ensures balance between genders.

We analysed the corporate governance annual reports published at the year-end on the Borsa Italiana web-site for each company in order to collect information about the name of each director engaged on the boards examined. Then we analysed more than 2,000 resumés with the aim of gathering information about gender, independence or lack thereof, age, whether they were graduates or not and types of degree, study abroad, and work experience.

We collected the leverage ratio for each company examined from the Orbis database and we calculated the average leverage ratio for each sector considered in the analysis. Then we compared the leverage ratio of each company belonging to each sector with the sector average leverage ratio; the firm with a leverage ratio higher 
than the sector average leverage ratio is considered aggressive.

Thus the dependent variable in this paper, named 'aggressive' get 0 in the case the firm leverage ratio is lower than the sector leverage ratio the firm belongs to; it get 1 in the case the firm leverage ratio is higher than the sector leverage ratio the firm belongs to. Table 1 shows the distribution of the sample among sectors and the number of aggressive firms; Table 2 presents and describes the variables used in the analysis.

Table 1. The sample distribution among sectors and the number of aggressive firms (2011-2013)

\begin{tabular}{ccccc}
\hline & \multicolumn{4}{c}{ Sector } \\
\cline { 2 - 5 } & Industrial & Consumer goods and services & Public service & Tot \\
\hline Number of observations & 192 & 78 & 108 & 378 \\
Number of aggressive firms & 74 & 28 & 36 & 138 \\
\hline
\end{tabular}

Table 2. The variables used in the analysis

\begin{tabular}{|c|c|}
\hline Variables & Description \\
\hline \multicolumn{2}{|c|}{ Dependent variable } \\
\hline aggressive & $\begin{array}{l}\text { Is a dichotomic variable }(0-1) \text {. If } 1 \text { it identifies a firm with a leverage ratio higher than the sector average } \\
\text { leverage ratio. }\end{array}$ \\
\hline \multicolumn{2}{|c|}{ Independent variables } \\
\hline \%women & Is the percentage of females on each board for each company. \\
\hline \%ind & Is the percentage of independent directors on the board for each company. \\
\hline age & Is the average age of board members per each company. \\
\hline$\%$ graduates & Is the percentage of graduate members for each company. \\
\hline \%law_graduates & Is the percentage of Law degrees on each board for each company. \\
\hline \%eco_graduates & Is the percentage of degrees in Economics for each board for each company. \\
\hline \%eng_graduates & Is the percentage of Engineering graduates for each board for each company. \\
\hline$\%$ accountants & Is the percentage of accountants on each board for each company. \\
\hline \%lawyers & Is the percentage of lawyers per each board for each company. \\
\hline \%engineers & Is the percentage of engineers in each board for each company. \\
\hline \%professors & Is the percentage of academic professors in each board for each company. \\
\hline \%entrepreneurs & Is the percentage of entrepreneurs or businessman on each board for each company. \\
\hline \%studyabroad & Is the percentage of directors who studied abroad. \\
\hline inter_skills & Is the percentage of board members with international skills and experience. \\
\hline n_directors & Is the number of directors in each board at the year-end. \\
\hline tot_asset & Is the logarithm of the total asset at the year-end. \\
\hline
\end{tabular}

To test the impact of the concentration and the diversification of degrees amongst board members for each board of directors, the Herfindahl Hirschman Index (HHI) (Note 1) is calculated using the following equation:

$$
H H I_{i}=\sum_{\substack{i=1 \\ t=2011}}^{2013}\left(s_{i, t} \times 100\right)^{2}
$$

In equation 1, $s_{i, t}$ is the percentage of degrees in Economics, in Law or in Engineering, $i$ identifies the company examined from 1 to 126 per year $\mathrm{t}$ from 2011 to 2013. Using this index we can obtain the level of concentration for each degree considered and the level of degree diversification per board of directors. We also use the same index to calculate the level of concentration and/or diversification per each board of directors considering the work experiences of each member.

We include three control variables in our analysis. The first one is the board size that is not a truly demographic attribute, but it is an important and much-studied board charateristic that is likely to have important effects on board functioning. Larger boards are likely to have more knowledge and skills at their disposal and the abundance of perspectives they assemble are likely to enhance cognitive conflict. However, at the same time, the difficulty inherent in coordinating the contributions of many members is likely to make it difficult for them to use their knowledge and skills effectively. Large boards may also have difficulty building interpersonal relationships owing to the potential for 'social loafing' that exists in large groups (Latané et al., 1979). The 
second one is related to the sector (sector: industrial, consumer goods and services and public services) each company belongs to, and the third one is related to the total asset (tot_asset) at the year-end.

Table 3 summarizes the descriptive statistics of the variables used in the analysis while the correlations between the independent variables used in the survey are shown in Table 4.

Table 3. Descriptive statistics ( $\mathrm{N}=378$; year 2011-2012-2013)

\begin{tabular}{|c|c|c|c|c|}
\hline Variable & Mean & Std. Dv. & Min & Max \\
\hline \multicolumn{5}{|c|}{ Dependent Variable: aggressive } \\
\hline Overall & 0.3651 & 0.4820 & 0 & 1 \\
\hline Between & & 0.4471 & & \\
\hline Within & & 0.1833 & & \\
\hline \multicolumn{5}{|l|}{ Independent Variables } \\
\hline \%women & 0.1231 & 0.1065 & 0 & 0.5 \\
\hline Between & & 0.0766 & & \\
\hline Within & & 0.0743 & & \\
\hline \%ind & 0.4478 & 0.1802 & 0.14 & 1 \\
\hline Between & & 0.1287 & & \\
\hline Within & & 0.1264 & & \\
\hline age & 57.53 & 4.6523 & 45.69 & 69 \\
\hline Between & & 3.5039 & & \\
\hline Within & & 3.0711 & & \\
\hline$\%$ graduates & 0.79 & 0.1929 & 0.2 & 1 \\
\hline Between & & 0.1510 & & \\
\hline Within & & 0.1205 & & \\
\hline \%law_graduates & 0.1264 & 0.1187 & 0 & 0.57 \\
\hline Between & & 0.0937 & & \\
\hline Within & & 0.0731 & & \\
\hline$\%$ eco_graduates & 0.3485 & 0.1765 & 0 & 0.71 \\
\hline Between & & 0.1334 & & \\
\hline Within & & 0.1160 & & \\
\hline$\%$ eng_graduates & 0.1524 & 0.1543 & 0 & 0.71 \\
\hline Between & & 0.1156 & & \\
\hline Within & & 0.1027 & & \\
\hline$\%$ accountants & 0.1223 & 0.1257 & 0 & 0.57 \\
\hline Between & & 0.0987 & & \\
\hline Within & & 0.0783 & & \\
\hline \%lawyers & 0.0614 & 0.0766 & 0 & 0.44 \\
\hline Between & & 0.0572 & & \\
\hline Within & & 0.0511 & & \\
\hline \%engineers & 0.0140 & 0.0412 & 0 & 0.22 \\
\hline Between & & 0.0307 & & \\
\hline Within & & 0.0277 & & \\
\hline \%professors & 0.0727 & 0.0986 & 0 & 0.45 \\
\hline Between & & 0.0754 & & \\
\hline Within & & 0.0636 & & \\
\hline \%entrepreneurs & 0.0693 & 0.1044 & 0 & 0.67 \\
\hline Between & & 0.0747 & & \\
\hline Within & & 0.0731 & & \\
\hline studyabroad & 0.16 & 0.1713 & 0 & 0.67 \\
\hline Between & & 0.1224 & & \\
\hline Within & & 0.1202 & & \\
\hline int_skills & 0.2601 & 0.1953 & 0 & 0.82 \\
\hline Between & & 0.1579 & & \\
\hline Within & & 0.1154 & & \\
\hline
\end{tabular}




\begin{tabular}{|c|c|c|c|c|}
\hline n_directors & 9.7407 & 3.1178 & 4 & 23 \\
\hline Between & & 2.2318 & & \\
\hline Within & & 2.1830 & & \\
\hline tot_asset & 13.3504 & 1.8940 & 9.14 & 18.96 \\
\hline Between & & 1.8961 & & \\
\hline Within & & 0.1056 & & \\
\hline
\end{tabular}

Note. This table presents the main descriptive statistics of the variables considered in the survey: aggressive is a dichotomic variable (0-1) that indicates if the company leverage ratio is higher than the sector average leverage ratio; \%women is the percentage of females on each board for each company; \%ind is the percentage of independent directors on the board for each company; age is the average age of board members per each company; \%graduates is the percentage of graduate members for each company; \%law_graduates is the percentage of Law degrees on each board for each company; \%eco_graduates is the percentage of degrees in Economics for each board for each company; \%eng_graduates is the percentage of Engineering graduates for each board for each company; \%accountants is the percentage of accountants on each board for each company; \%lawyers is the percentage of lawyers per each board for each company; \%engineers is the percentage of engineers in each board for each company; \%professors is the percentage of academic professors on each board for each company; \%entrepreneurs is the percentage of entrepreneurs or businessman on each board for each company; \%studyabroad is the percentage of directors who studied abroad; inter_skills is the percentage of board members with international skills and experience; n_directors is the number of directors in each board; tot_asset is the logarithm of the total asset at the year-end.

Table 4. Matrix correlation

\begin{tabular}{|c|c|c|c|c|c|c|c|c|c|c|c|c|c|c|c|c|}
\hline & 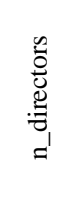 & $\begin{array}{l}0 \\
0 \\
\tilde{\Xi} \\
\tilde{\Xi} \\
0 \\
\vdots \\
0 \\
0\end{array}$ & 音 & $\underset{\pi}{\mathbb{\infty}}$ & 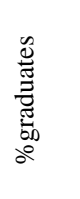 & 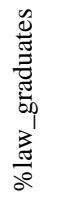 & 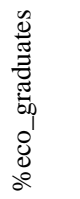 & 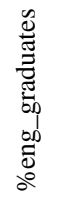 & 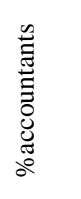 & $\frac{\sqrt[5]{0}}{\frac{5}{0}}$ & 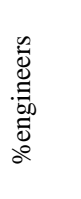 & 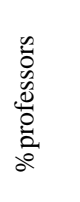 & 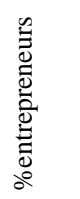 & 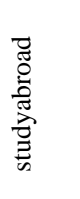 & 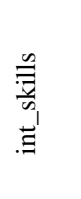 & 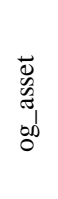 \\
\hline $\mathrm{n} \_$directors & 1 & & & & & & & & & & & & & & & \\
\hline \%women & -0.06 & 1 & & & & & & & & & & & & & & \\
\hline \%ind & 0.11 & -0.14 & 1 & & & & & & & & & & & & & \\
\hline age & 0.21 & -0.19 & 0.07 & 1 & & & & & & & & & & & & \\
\hline$\%$ graduates & 0.22 & 0.04 & 0.09 & 0.05 & 1 & & & & & & & & & & & \\
\hline \%law_graduates & 0.18 & -0.21 & 0.10 & 0.13 & 0.28 & 1 & & & & & & & & & & \\
\hline$\%$ eco_graduates & 0.06 & 0.02 & 0.07 & -0.08 & 0.36 & -0.01 & 1 & & & & & & & & & \\
\hline \%eng_graduates & 0.02 & 0.08 & -0.08 & 0.11 & 0.28 & -0.22 & -0.32 & 1 & & & & & & & & \\
\hline \%accountants & -0.02 & 0.10 & -0.05 & -0.22 & 0.04 & -0.07 & 0.35 & -0.21 & 1 & & & & & & & \\
\hline \%lawyers & 0.09 & -0.15 & 0.09 & -0.04 & 0.21 & 0.59 & 0.08 & -0.19 & 0.01 & 1 & & & & & & \\
\hline \%engineers & 0.13 & -0.09 & -0.05 & 0.05 & 0.10 & -0.11 & -0.04 & 0.24 & 0.13 & 0.04 & 1 & & & & & \\
\hline \%professors & 0.26 & 0.03 & 0.15 & 0.06 & 0.20 & -0.04 & -0.07 & 0.23 & -0.17 & -0.03 & -0.03 & 1 & & & & \\
\hline$\%$ entrepreneurs & -0.07 & -0.10 & -0.10 & -0.03 & -0.13 & 0.02 & 0.05 & -0.18 & -0.06 & 0.08 & -0.15 & -0.24 & 1 & & & \\
\hline studyabroad & 0.03 & 0.05 & 0.10 & 0 & 0.35 & 0.06 & 0.08 & 0.27 & -0.30 & -0.03 & -0.05 & 0.06 & -0.08 & 1 & & \\
\hline int_skills & 0.15 & 0 & 0.12 & 0.10 & 0.39 & 0.03 & 0.10 & 0.35 & -0.22 & -0.07 & 0.08 & 0.10 & -0.10 & 0.68 & 1 & \\
\hline log_asset & 0.20 & -0.05 & 0.24 & 0.09 & 0.19 & 0.13 & 0.14 & 0 & 0.03 & -0.03 & -0.01 & 0.22 & -0.10 & 0.13 & 0.19 & 1 \\
\hline
\end{tabular}

Note. This table shows the correlation between the variables used in the model: \%women is the percentage of females on each board for each company; \%ind is the percentage of independent directors on the board for each company; age is the average age of board members per each company; \%graduates is the percentage of graduate members for each company; \%law_graduates is the percentage of Law degrees on each board for each company; \%eco_graduates is the percentage of degrees in Economics for each board for each company; \%eng_graduates is the percentage of Engineering graduates for each board for each company; \%accountants is the percentage of accountants on each board for each company; \%lawyers is the percentage of lawyers for each board for each company; \%engineers is the percentage of engineers on each board for each company; \%professors is the percentage of academic professors on each board for each company; \%entrepreneurs is the percentage of entrepreneurs or businessman on each board for each company; \%studyabroad is the percentage of directors who studied abroad; inter_skills is the percentage of board members with international skills and experience; $n$ _directors is the number of directors on each board; tot_asset is the logarithm of the total asset at the year-end.

The methodology used in this paper comprises three steps: Step 1 is designed to study the relationship between the board members' educational background and the company risk level; Step 2 studies the relationship between the board members' work experiences and the company risk level and Step 3 considers the concentration and the diversification of graduates and work experiences inside the boards examined in relationship with the decision of 
whether to be an aggressive firm or not.

Step 1: educational background analysis

To test the impact of educational background on the company risk level, we used the following regressions (please see Table 2 for the variables description):

$$
\begin{gathered}
\text { aggressive }=\alpha_{1+} \beta_{1} \% \text { women }+\beta_{2} \% \text { ind }+\beta_{3} \text { age }+\beta_{4} \% \text { graduates }+\beta_{5} \% \text { law } w_{\text {graduates }}+\beta_{6} \% \text { eco_graduates } \\
+\beta_{7} \% \text { eng_graduates }+\beta_{8} \% \text { studyabroad }+\beta_{9} n_{-} \text {directors }+\beta_{10} \text { tot_asset }+\sum_{i=1}^{3} \gamma_{i} \text { sector }_{i}+\sum_{j=1}^{3} \lambda_{i} t_{j}+\varepsilon
\end{gathered}
$$

Step 2: work experiences analysis

To test the impact of directors' work experience on the company risk level, we used the following regressions (please see Table 2 for the variables description):

$$
\begin{gathered}
\text { aggressive }=\alpha_{1}+\beta_{1} \% \text { women }+\beta_{2} \% \text { ind }+\beta_{3} \% \text { age }+\beta_{4} \% \text { accountants }+\beta_{5} \% \text { lawyers }+\beta_{6} \% \text { engineers } \\
+\beta_{7} \% \text { professors }+\beta_{8} \% \text { entrepreuners }+\beta_{9} \text { inter_skills }+\beta_{10} n_{\text {directors }}+\beta_{11} \text { tot_asset } \\
+\sum_{i=1}^{3} \gamma_{i} \text { sector }{ }_{i}+\sum_{j=1}^{3} \lambda_{i} t_{j}+\varepsilon
\end{gathered}
$$

Step 3: concentration/diversification analysis

To test the relationship between the concentration of degrees and the concentration of work experiences inside the board of directors and the company risk level, we used the following regressions (please see Table 2 for the variables description):

$$
\begin{gathered}
\text { aggressive }=\alpha_{1}+\beta_{1} \% \text { women }+\beta_{2} \% \text { ind }+\beta_{3} \text { age }+\beta_{4} \% \text { graduates }+\beta_{5} \text { law }_{\text {conc }}+\beta_{6} \text { eco }_{\text {conc }}+\beta_{7} \text { eng }_{\text {conc }} \\
+\beta_{8} \text { accountants }_{\text {conc }}+\beta_{9} \text { lawyers }_{\text {conc }}+\beta_{10} \text { engineer }_{\text {conc }}+\beta_{11} \text { prof_conc } \\
+\beta_{12} \text { entrepreuners_conc }+\beta_{13} n_{-} \text {directors }+\beta_{14} \text { tot_asset }+\sum_{i=1}^{3} \gamma_{i} \text { sector }{ }_{i}+\sum_{j=1}^{3} \lambda_{i} t_{j}+\varepsilon
\end{gathered}
$$

where law_conc, eco_conc and eng_conc are dummies ( 0 or 1$)$ that indicate respectively the concentration of degrees in Law, in Economics and in Engineering calculated with the HHI for each board for each company; accountants_conc, lawyers_conc, engineers_conc, prof_conc and entrepreners_conc are dummies (0 or 1) that indicate respectively the concentration of accountants, lawyers, engineers, professors and entrepreneurs calculated with the HHI for each board for each company; $\varepsilon$ represents error.

To test the relationship between the diversification of degrees and of the work experiences inside the board of directors and the company risk level, we used the following regressions (please see Table 2 for the variables description):

$$
\begin{aligned}
& \text { aggressive }=\alpha_{1}+\beta_{1} \% \text { women }+\beta_{2} \% \text { ind }+\beta_{3} \text { age }+\beta_{4} \% \text { graduates }+\beta_{5} \text { studies_div } \\
& \quad+\beta_{6} \text { works_div }+\beta_{7} n \_ \text {directors }+\beta_{8} \text { tot_asset }+\sum_{i=1}^{3} \gamma_{i} \text { sector }{ }_{i}+\sum_{j=1}^{3} \lambda_{i} t_{j}+\varepsilon
\end{aligned}
$$

where $\alpha_{1}$ is a constant; studies_div and work_div are two dummy variables ( 0 or 1$)$ which indicates the diversification of degrees and of the work experiences amongst the board members calculated with the HHI for each board for each company; $\varepsilon$ represents error.

\section{Empirical Results}

\section{Step 1 - Educational background analysis}

The results obtained by equation (2) are shown in Table 5. On the one hand, they highlight that the more graduates present on the board, the more aggressive the firms tend to be; on the other hand, the more degrees in Law and in Economics sitting on the board and the less aggressive the firms are.

Table 5. The educational background regression results

\begin{tabular}{ll}
\hline \%women & 2.111 \\
& $(4.334)$ \\
\%ind & -2.491 \\
& $(2.660)$ \\
age & -0.0991 \\
& $(0.0938)$ \\
\%graduates & $4.755^{*}$ \\
& $(2.829)$ \\
& $-14.18^{* * *}$ \\
& $(4.078)$ \\
\hline
\end{tabular}




\begin{tabular}{ll}
\hline \%eco_graduates & $-6.048^{*}$ \\
\%eng_graduates & $(3.131)$ \\
& -4.329 \\
\%studyabroad & $(4.042)$ \\
& 3.608 \\
n_directors & $(2.837)$ \\
& -0.0597 \\
tot_asset & $(0.146)$ \\
& 0.333 \\
macro1 & $(0.321)$ \\
& -0.642 \\
macro3 & $(1.274)$ \\
& -0.832 \\
t1 & $(1.412)$ \\
& $3.503 * * *$ \\
t2 & $(0.939)$ \\
& $2.797 * * *$ \\
Constant & $(0.928)$ \\
& 0.477 \\
N. Obs & $(7.511)$ \\
\hline Prob $>\chi^{2}$ & 378 \\
\hline
\end{tabular}

Note. This table presents the main results of our educational background analysis. To remind you: \%women is the percentage of females on each board for each company; \%ind is the percentage of independent directors on the board for each company; age is the average age of board members for each company; \%graduates is the percentage of graduate members for each company; \%law_graduates is the percentage of Law degrees on each board for each company; \%eco_graduates is the percentage of degrees in Economics for each board for each company; \%eng_graduates is the percentage of Engineering graduates for each board for each company; \%studyabroad is the percentage of directors who studied abroad; $n$ _directors is the number of directors on each board; tot_asset is the logarithm of the total asset at the year-end; sector indicates the macro-sectors the companies examined belong to (industrial, consumer goods and services, and public services respectively).

This result confirms our hypothesis H4, probably because they are more aware of the high probability of default in the case of a high leverage ratio and the dramatic consequences. Degrees in Economics and in Law tend to reduce the company risk level. Thus, different degrees do not confer the same skills and knowledge.

Step 2 - Works experience analysis

Faced with the results obtained by equation (3) related to the work experiences analysis shown in Table 6, two main results are highlighted. The first one is that lawyers tend to be more risk adverse, confirming the result obtained in Step 1. According to the second one, the more engineers sitting on the board and the more aggressive the company tends to be, but probably without the adequate awareness.

Table 6. The work experience regression results

\begin{tabular}{ll}
\hline \%women & 2.747 \\
& $(3.956)$ \\
\%ind & -0.356 \\
& $(2.551)$ \\
age & $-0.219^{* *}$ \\
& $(0.0950)$ \\
\%accountants & 0.358 \\
& $(4.257)$ \\
\%lawyers & $-22.48^{* * *}$ \\
& $(5.312)$ \\
& $27.27 * * *$ \\
\hline
\end{tabular}




\begin{tabular}{ll}
\hline \%professors & 5.268 \\
& $(4.809)$ \\
\%entrepreuners & 3.462 \\
& $(5.117)$ \\
inter_skills & 0.644 \\
& $(2.588)$ \\
n_directors & 0.0527 \\
& $(0.153)$ \\
tot_asset & $0.483 *$ \\
& $(0.278)$ \\
macro1 & -0.742 \\
& $(1.158)$ \\
macro3 & -0.856 \\
& $(1.479)$ \\
t1 & $3.690 * * *$ \\
& $(0.875)$ \\
t2 & $2.683 * * *$ \\
& $(0.885)$ \\
Constant & 2.707 \\
& $(7.218)$ \\
\hline N. Obs & 378 \\
Prob $>\chi^{2}$ & 0.000 \\
\hline
\end{tabular}

Note. This table presents the main results of our work experience analysis. To remind you: \%women is the percentage of females on each board for each company; \%ind is the percentage of independent directors on the board for each company; age is the average age of board members for each company; \%accountants is the percentage of accountants on each board for each company; \%lawyers is the percentage of lawyers for each board for each company; \%engineers is the percentage of engineers on each board for each company; \%professors is the percentage of academic professors on each board for each company; \%entrepreneurs is the percentage of entrepreneurs on each board for each company; inter_skills is the percentage of board members with international skills and experience; n_directors is the number of directors per board; tot_asset is the logarithm of the total asset at the year-end; sector indicates the macro-sectors the companies examined belong to (industrial, consumer goods and services, and public services respectively).

Moreover, as indicated by the literature, the results obtained highlighted that older boards of directors tend to reduce the firm leverage ratio, thus our $\mathrm{H} 3$ is confirmed.

\section{Step 3: Concentration/diversification analysis}

Table 7 shows two kinds of results from equations (4) and (5) respectively: the one related to the educational and work experiences concentration and the one related to the educational and work experiences diversification.

Table 7. Concentration and diversification regression results

\begin{tabular}{llll}
\hline Concentration analysis - Eq (4) & & Diversification analysis - Eq (5) & \\
\hline \%women & 3.751 & \%women & $(3.289)$ \\
& $(4.005)$ & & -0.233 \\
\%ind & 1.695 & \%ind & $(2.164)$ \\
& $(2.540)$ & & $-0.208^{* *}$ \\
age & $-0.197 * *$ & age & $(0.0887)$ \\
& $(0.100)$ & & $7.057 * * *$ \\
\%graduates & 3.258 & \%graduates & $(2.223)$ \\
& $(2.381)$ & & 0.479 \\
law_conc & 39.14 & works_div & $(0.988)$ \\
& $(8,459)$ & & $4.447 * * *$ \\
eco_conc & $-2.362 * *$ & studies_div & $(1.167)$ \\
& $(1.066)$ & & -0.191 \\
eng_conc & 0.336 & n_directors & $(0.119)$ \\
\hline
\end{tabular}




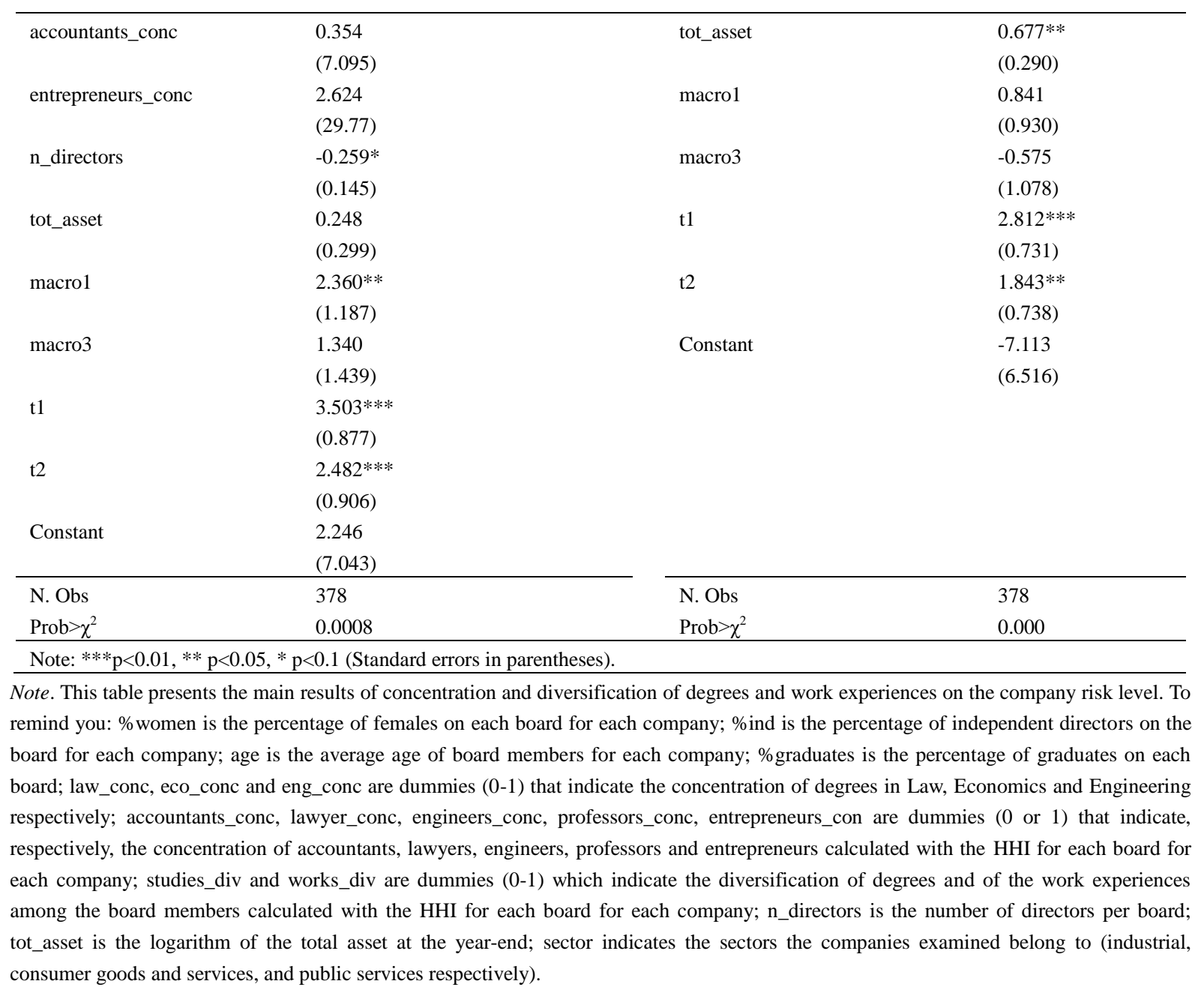

In terms of concentration, the main result obtained is that the concentration of degrees in Economics tend to be more conservative in decision making thus the firm is less aggressive. This result confirms and reinforces the one obtained in Step 1. There is no other significant relationship between educational or work experience concentration and the decision making regarding the firm's leverage ratio. Instead, it is confirmed that an older board tends to be less aggressive.

The diversification analysis confirms the previous result according to which the more degrees sitting on the board and the more aggressive the firms are. Moreover, the diversification of degrees tends to increase the leverage ratio of the firms examined. According to the authors, this result can be explained because the presence of heterogeneous degrees can make communication difficult among board members or directors that might not have specific expertise in corporate governance. However people very often tend not to admit their limitations, being overconfident and often guided by optimism and take decisions that are likely to be risky. The last result of this step of analysis is that the larger the board of directors, the less aggressive the firms are. Our hypotheses 1 and 2 are rejected. In fact, according to the results of this paper, women and independent directors have no significant impact on the company leverage ratio.

\section{Conclusions}

The board of directors' decision making is fundamental to company prosperity over time. Many studies in literature examined the quantitative characteristics of boards of directors while very few studies considered the quality of its members, the directors. This study extends the literature about corporate governance and about the group-decision making by examining the composition of a sample of Italian listed company boards and also by analyzing the impact of the same members' demographic characteristics and the companies risk level. In particular we test four hypotheses: 1) a large number of female directors reduces the company risk level. This hypothesis is rejected. 2) a large number of independent directors reduces the company risk level. This hypothesis is rejected. 3) older boards of directors tend to reduce the company risk level. This hypothesis is 
confirmed. 4) having a degree in Economics reduces the company risk level. This hypothesis is confirmed. The results are particularly interesting because, on the one hand, they confirm some existing studies and, on the other hand, they open a new debate that may be of interest to the regulator, companies and investors.

Based on the results obtained in this study, we are able to argue that the level of skills necessary to participate in corporate governance is not acquired with any kind of degree. We demonstrate that being a graduate is not enough to help company growth. In particular, based on the results obtained in this survey it is possible to identify a board composition that prefers degrees in Economics and in Law, in particular a concentration of degrees in Economics is well accepted in the aim of reducing the company risk level; lawyers operate in the same way while engineers seem to have a higher risk tendency. The diversification of work experiences has no impact on the company risk level; the diversification of degrees seems to drive board decision-making to a high risk level of the firm.

Future researches might try to pursue this issue in order to provide new supports for regulators, for the institutional investors and for the whole market.

\section{References}

Adams, R., \& Ferreira, D. (2009). Women in the boardroom and their impact on governance and performance. Journal of Financial Economics, 94(2), 291-309. https://doi.org/10.1016/j.jfineco.2008.10.007

Agrawal, K. (2015). Default prediction using Piotroski's F-scrore. Global Business Review, 16(5s), 175s-186s. https://doi.org/10.1177/0972150915601261

Anderson, R., Reeb, D., Upadhay, A., \& Zhao, W. (2011). The Economics of Director Heterogeneity. Financial Management, 40, 5-38. https://doi.org/10.1111/j.1755-053X.2010.01133.x

Audretsch, D., \& Lehmann, E. (2006). Entrepreneurial Access and Absorption of Knowledge Spillovers: Strategic Board and Managerial Composition for Competitive Advantage. Journal of Small Business Management, 44, 155-166. https://doi.org/10.1111/j.1540-627X.2006.00161.x

Barber, B., \& Odean, T. (2000). Trading is hazardous to your wealth: The common stck investment performance of individual investors. Journal of Finance, 55, 773-806. https://doi.org/10.1111/0022-1082.00226

Beasley, M. (1996). An Empirical Analysis of the Relation between the Board of Director Composition and Financial Statement Fraud. The Accounting Review, 71(4), 443-465.

Botwinick, J. (1977). Aging and Behavior. New York: Springer.

Burke, D., \& Light, L. (1981). Memory and aging: The role of retrieval processes'. Psychological Bulletin, 90 , 513-546. https://doi.org/10.1037/0033-2909.90.3.513

Campbell, D. (1987). Inkling-issues and observations. Issue and Observations, 7(2), 7-8.

Carlson, R., \& Karlsson, K. (1970). Age, cohorts, and the generation of generations. American Strategical Review, 35, 710-718. https://doi.org/10.2307/2093946

Carter, D., Simkins, B., \& Simpson, W. (2003). Corporate Governance, Board Diversity, and Firm Value. Financial Review, 38, 33-53. https://doi.org/10.1111/1540-6288.00034

Christy, J., Matolcsy, Z., Wright, A., \& Wyatt, A. (2010). The association between the market risk of equity and board characteristics. Working paper, University of Technology, Sydney.

Datta, D., \& Rajagopalan, N. (1998). Industry structure and CEO characteristics: An empirical study of $\begin{array}{lllll}\text { seccession events. Strategic Management Journal, } & \text { 19(9), 833-852. }\end{array}$ https://doi.org/10.1002/(SICI)1097-0266(199809)19:9<833::AID-SMJ971>3.0.CO;2-V

Fama, E., \& Jensen, M. (1983, June). Separation of ownership and control. Journal of Law and Economics, 26 , 301-325. https://doi.org/10.1086/467037

Forbes, D., \& Milliken, F. (1999). Cognition and corporate governance: Understanding boards of directors as strategic decision-making groups. Academy of Management, 24(3), 489-505.

Gul, F., Srinidhi, B., \& Ng, A. (2011). Does Board Gender Diversity Improve the Informativeness of Stock Prices? Journal of Accounting and Economics, 51, 314-338. http://dx.doi.org/10.1016/j.jacceco.2011.01.005

Guthrie, J., \& Olian, J. (1991). Does context affect staffing decision? The case of general managers. Personnel Psychology, 44, 263-292. https://doi.org/10.1111/j.1744-6570.1991.tb00959.x 
Hambrick, D., \& Mason, P. (1984). Upper echelors: the organization as a reflection of its top managers. Accademy of Management Review, 9(2), 193-206.

Janis, I. (1971). Groupthink. Psychology Today, 5, 43-46, 74-76.

Kahneman, D. (2011). Thinking Fast and Slow New York: Farrar, Strauss, Giroux.

Kahneman, D., \& Lovallo, D. (1993). Timid chices and bold forecasts: A cognitive perspective on risk taking. Management Science, 39, 17-31. https://doi.org/10.1287/mnsc.39.1.17

Latané, B., Williams, K., \& Harkins, S. (1979). Many hands make light the work: The causes and consequences of social loafing. Journal of Personality and Social Psychology, 37, 822-832. https://doi.org/10.1037/0022-3514.37.6.822

Litov, L., Sepe, S., \& Whitehead, C. (2013). Lawyers and Fools: Lawyer-Directors in Public Coroporations. University of Arizona, Unpublished working paper. https://doi.org/10.2139/ssrn.2218855

Lundberg, M., Fox, P., \& Punccohar, J. (1994). Highly confident but wrong: Gender differences and similarities in confidence judgements. Journal of Educational Psychology, LXXXVI, 114-121. https://doi.org/10.1037/0022-0663.86.1.114

Mallin, C. (2004). Corporate governance. Oxford: Oxford University Press.

Milliken, F., \& Martins, L. (1996). Searching from common threads: Understanding the multiple effects of diversity in organizational groups. Academy of Management Review, 21, 402-433.

Monks, R., \& Minow, N. (2003). Corporate governance (3rd ed.). Madden, MA: Blackwell Publishing Ltd.

Tsai, H. F., Lin, T. J., \& Hung, J. H. (2015). The effects of the split share structure reform on Chinese listed firms leverage decisions. The Quarterly Review of Economics and Finance, 57, 85-100. http://dx.doi.org/10.1016/j.qref.2014.10.003

Vroom, V., \& Pahl, B. (1971). Relationships between age and risk-taking among managers. Journal of Applied Psychology, 55, 399-405. https://doi.org/10.1037/h0031776

Wailderdsak, N., \& Suehiro, A. (2004). Top executive origins: Comparative study between Thailand and Japan. Asian Business and Management, 3, 85-104. https://doi.org/10.1057/palgrave.abm.9200071

Wiersema, M., \& Bantel, K. (1992). Top management team demography and corporate strategic change. Accademy of Management Journal, 35(1), 91-121. https://doi.org/10.2307/256474

Williams, K., \& O’Reilly, C. (1998). Demography and diversity in organizations: A review of 40 years research. Research in Organizational Behavior, 20, 77-140.

\section{Note}

Note 1. The HHI is designed to measure industry concentration. The US Department of Justice associates the following threshold values with the HHI for particular use: an HHI below 1,000 signals a low concentration, while one above 1,800 signals a high concentration; an index between 1,000 and 1,800 shows a moderate concentration.

\section{Copyrights}

Copyright for this article is retained by the author(s), with first publication rights granted to the journal.

This is an open-access article distributed under the terms and conditions of the Creative Commons Attribution license (http://creativecommons.org/licenses/by/4.0/). 